\title{
MONETARY POLICY IN AFGHANISTAN: IS IT EFFICIENT
}

\author{
Kawoon Azizi \\ Lecturer in Economic Faculty \\ Banking Department \\ Nangarhar University, Nangarhar, Afghanistan
}

\author{
Mohammad Hashim Daqiq \\ Lecturer in Economic Faculty \\ Business Administration Department \\ Kandahar University, Kandahar, Afghanistan
}

\begin{abstract}
This study tries to assess the central bank of Afghanistan's monetary policy towards targeting important economic variables e.g. inflation, changing the exchange rate and bringing price stability. To do the analysis at the first stage importance of exchange rate discussed with the help of correlation analysis and further for the analysis two separate regression models were used. The first model examined the relationship between exchange rate, foreign currency, and capital notes sold on the market. The second model concentrated on understanding the relationship between the amounts of narrow and broad money in circulation and the CPI. The data for the analysis collected from Afghanistan central statistical organization (CSO), central bank yearly reports, and via direct contact to central bank's supervision department. The accessible data was from April 2012 to December 2018 which is in total 81 months. The results of the correlation analysis of macroeconomic indicators with exchange rate shows that most of the indicators has correlation with exchange rate by having $R^{2}$ more than 50 percent, however only GDP growth has significant p-value at 0.05 level. Result of the first model show that only 40 percent of changes to the exchange rate were caused by Da Afghanistan Bank selling foreign currency and capital notes. The coefficient related to the effect of the sale of foreign currency on the exchange rate had a negative sign, with a significant p-value. However, the coefficient of capital notes had positive sign, which goes against the theoretical argument behind the sale of capital notes. The results of the second model show that changes in the amounts of narrow money and broad money are responsible for $\mathbf{4 7}$ percent of changes in the CPI. However, the impact is weak and huge changes in the amount of money in circulation are required to change the CPI. Overall, it could be argued that the monetary policy of the central bank is more effective at influencing the exchange rate, but the government should also consider other factors which influence the price stability.
\end{abstract}

Keywords - Inflation, Price Stability, Money Supply, Exchange Rate, Consumer Price Index

\section{INTRODUCTION}

Monetary policy is a set of measures used by a central bank to regulate the value, supply and cost of money in consonance with the estimated level of economic transactions or activity in an economy (Folawewo and Osinubi, 2008). Normally, the job of central banks around the world is to promote macroeconomic stability or price stability by using the monetary policy tools available to them. This is done because price instability means rising inflation and threatens the economic progress of a country (Babatunde and Kehinde, 2016).

Defining price stability means choosing between price-level stability and low (including zero) inflation, choosing a suitable price index, and selecting a suitable level as a quantitative target. Furthermore, maintaining price stability involves deciding how important real variables like output are in terms of the objectives of monetary policy (Svensson, 1999).

The most important role of a central bank is to conduct monetary policy so as to achieve its objective of price stability (low or stable inflation) and to play an active role in managing economic fluctuations. There are many studies which explain the important impact of monetary policy on price stability.

Amarasekara (2007) analyzed the impact of interest rate, growth in the supply of money and movement of the nominal exchange rate on real GDP and inflation in Sri Lanka. The results of this study showed that positive innovation in interest rate caused GDP to grow and inflation to decrease, while appreciation of the exchange rate had an instant impact, reducing the rate of inflation.

Chuku (2009), studied the impact of monetary policy in Nigeria by considering three monetary policy tools: broad 


\section{International Journal of Engineering Applied Sciences and Technology, 2019}

Vol. 4, Issue 4, ISSN No. 2455-2143, Pages 19-28

Published Online August 2019 in IJEAST (http://www.ijeast.com)

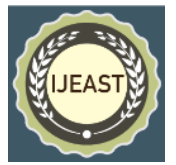

money, minimum rediscount rate, and real effective exchange rate. The results showed that changes in the amount of broad money had a more immediate effect on prices and output, while changes in the minimum rediscount rate and real exchange rate had a neutral and fleeting effect on prices and output. This means that the quantity of money in the economy is the most influential factor used to control prices.

Akinbobola (2012) used empirical analysis to examine the impact of money supply and exchange rate on inflation in Nigeria. The results of his study showed that money supply and exchange rate have a high, negative impact on inflationary pressure in long run. However, changes in foreign prices and real output have a direct impact on inflationary pressure. Furthermore, Madume and Nenbee (2011) studied the impact of monetary policy on the stability of macroeconomic variables in Nigeria. Their findings showed that monetary policy tools had conflicting impacts on inflation.

Rao Manohar (2003), studied the problems of monetary policy design within the limits of an empirical framework in India. In this study, he first looked at the main characteristics of business cycles. Secondly, he empirically measured the threshold rate of inflation. Thirdly, he made a theoretical model to link growth, inflation, money supply and interest rate. Finally, he provided predictions of a comprehensive macroeconomic conditions index which can very efficiently be combined into a simple, Taylor-type interest rate rule (reaction function) for monetary policy. The results showed that ever since liberalization, there has been a surge of interest in streamlining the operational framework of monetary policy.

Like other countries' central banks, DAB took responsibility once again in 2003 and started to implement monetary policy with the stated vision of being "a monetary institution which upholds international best practice in fostering price stability and a sound financial system conducive to macro-economic stability, and broad-based economic growth" (DAB, 2018). The main objectives of DAB, which are stated in its own laws, are to achieve and maintain domestic price stability and to support general economic policies of the government to strengthen sustainable economic growth. To maintain price stability, DAB have subordinated objectives: fostering the liquidity, solvency and effective functioning of a stable, market-based financial system, and promoting a safe, sound and efficient national payments system (2nd Article of DAB law, 2003).

Since 2003, DAB has used its reserves as the primary liquidity indicator, and has estimated its precise amount of reserves by considering the expected growth rate, the average level of inflation, and the changes in the aggregate demand for
Afghani over the year. Maintaining its reserve money is the DAB's most important operational target, while the amount of currency in circulation is set as an indicative target.

DAB generally uses only two monetary policy tools: auction of currency and capital notes. It sells foreign currencies to commercial banks and authorized money exchange dealers on a bi-weekly basis, and sells capital notes which mature after 7 , 28,182 or 364 days to commercial banks once a week to control the amount of money in its reserves (DAB Report, 2018).

In December 2018, DAB auctioned 256,710,000 US Dollars' worth of money and capital notes with a value of $33,725,000,000$ Afghani. DAB is not succeeding in maintaining price stability by using these two monetary policy tools and auctioning millions of US Dollars' worth of foreign currencies. According to the calculations of the Asian branch of worlddata.info, an item which cost 100 Afghani in 2004 cost 212.03 Afghani in 2016, an increase of 112.03 Afghani. The data published by data mundi (taken from CIA reports) shows large fluctuations in the inflation rate, e.g. 2003 (inflation 10.3\%), 2005 (16.3\%), 2007 (13\%), 2009 (13.3\%), $2011(10.2 \%), 2012(6.8 \%), 2016(4.5 \%)$, and $2017(6 \%)$ (indexmundi.com, 2019).

DAB's monetary policy mostly uses open market operations, selling foreign currencies and capital notes, to maintain price stability and lower the inflation rate. As the data shows, prices are increasing yearly and the inflation rate fluctuates a lot in Afghanistan. The reasons behind these fluctuations are not clear, as many factors could influence prices. Furthermore, DAB did not conduct any studies to check whether the monetary policy (controlling the supply of money) has a positive impact on price stability or not. By considering the ambiguous impact of money supply on price stability in Afghanistan, this study was designed to answer the following important questions:

- How efficient is money supply impact on price stability in the country?

- What are the determinants of Exchange Rate Volatility in the country?

- Does money supply influence exchange rates?

- To what level does the supply of money influence CPI in the market?

The study planned to test the following hypothesis:

- $\quad H_{0}=$ There is no correlation between Exchange rare and Inflation, FDI, GDP growth, Interest Rate, and Balance of Payment. 
- $H_{1}=$ The selected monetary policy variables have no significant impact on CPI in the Afghan Market.

To answer the questions above, an ordinary least squares (OLS) regression model was used, as will be explained in the following sections. This study aims to give DAB and other stakeholders (e.g. the World Bank and IMF) accurate and reliable information regarding the effectiveness of DAB's monetary policy, in order to allow them to provide evidencebased intervention to achieve price stability.

\section{DESCRIPTION OF DATA}

This study depends exclusively on secondary time series data which was collected from Da Afghanistan Bank (Afghanistan Central Bank/DAB) and Afghanistan Central Statistics Organization (CSO) yearly bulletins. Furthermore, the study reviewed reports from other sources, e.g. International Monetary Fund and the World Bank, to get data related to the exchange rate between the Afghani and the US Dollar and to further check the validity of the data published or issued by $\mathrm{DAB}$ and the CSO.

Monetary data was collected directly from the monetary department of DAB, as well as from DAB's yearly bulletin. Data related to the Consumer Price Index (CPI) was collected from the CSO. The study tried to collect data from the years before 2012, but due to a lack of data the study only had access to data from the years 2012 to 2018. This data included the CPI, the US Dollar versus Afghani exchange rate, capital notes awarded, foreign currency sold on the market, amount of narrow money, and amount of broad money in the market, all on a monthly basis. In total, the analysis used 81 months of data.

\section{FIELD RESEARCH DESIGN/ METHODS OF DATA ANALYSIS}

As the objective of this study is to analyze the effectiveness of DAB's monetary policy on maintaining price stability, data related to the monetary policy being implemented by the bank, the consumer price index and the exchange rate were needed. Data from the period 2012 to 2018 was considered. The data was collected from DAB and CSO. However, data from the IMF and the World Bank were used to confirm the validity of the data issued by DAB and CSO.

To analyze the collected data, at the first stage Pearson's correlation analysis is used to see the relationship between some important macroeconomic indicator e.g. GDP growth, Interest Rate, Current Account Balance, FDI net flow, and inflation rate with changes in exchange rate and then an ordinary least squares regression model (OLS) and a unit root test were used (as the data is time series) to show the relationship between the dependent and independent variables, e.g. money supply (MS), exchange rate (EXR) and Consumer Price Index (CPI), which is used as a proxy for the general price level, and is the main explained variable.

From a theoretical point of view, changes or increases in money supply from whatever source, should lead to an increase in the price level (inflation). The impact of the exchange rate on price stability is also related to the money supply. If the exchange rate rises or domestic currency depreciates, more money is required to be exchanged for one unit of foreign currency, with a consequent decrease in the domestic money supply.

By considering the theoretical background and objectives of the study, two OLS models were chosen.

\section{First Model}

The main objective of DAB is to use the monetary policy tools available to it to bring price stability to the market. Therefore, in the majority of cases, DAB sells foreign currency and capital notes to influence the exchange rate of the Afghani against the US Dollar, giving it control over the purchasing power of the Afghani. The first model focuses on the relationship between foreign currency sold, capital notes issued, and the exchange rate. The function used for the analysis is below.

$$
E X R=f(M S) \ldots \ldots \ldots \ldots(i)
$$

If we consider the relationship to be linear, we have

$$
Y_{1}=\beta_{0}+\beta_{1} x_{1}+\beta_{2} x_{2}+u
$$

In the above model:

$\mathbf{E X R}=\mathbf{Y}_{1}=$ exchange rate with respect to US Dollars

MS $=$ money supply

$\mathbf{x}_{\mathbf{1}}=$ foreign currency sold on the market

$\mathbf{x}_{\mathbf{2}}=$ capital notes awarded or sold on the market

$\boldsymbol{\beta}_{0}, \boldsymbol{\beta}_{1}$, and $\boldsymbol{\beta}_{2}=$ parameters

$\mathbf{u}=$ stochastic error term

\section{Second Model}

The second model focuses on the impact of narrow money (M1) and broad money (M2) on the CPI. In the model, narrow money is all the coin and cash in the market and broad money is all those assets which can be converted into cash. The model used for the analysis is below. 


$$
\begin{aligned}
& C P I=f(M 1, M 2) \ldots \ldots . . . \\
& Y_{I}=\beta_{0}+\beta_{1} x_{1}+\beta_{2} x_{2}+u \ldots .
\end{aligned}
$$

In the above model:

$\mathbf{M 1}=$ narrow money, $\mathbf{M 2}=$ broad money

$\mathbf{C P I}=\mathbf{Y}_{\mathbf{1}}=$ Consumer Price Index $(\mathrm{CPI})$

$\mathbf{x}_{1}=$ narrow money, $\mathbf{x}_{2}=$ broad money

$\boldsymbol{\beta}_{0}, \boldsymbol{\beta}_{1}$, and $\boldsymbol{\beta}_{2}=$ parameters, $\mathbf{u}=$ stochastic error term

\section{RESULTS}

\section{Correlation analysis of macroeconomic indicators}

As in the study the focus is on impact of exchange rate, therefore it is important to analyze the main determinants of exchange rate volatility. There are large number of variables which has direct or indirect impact on exchange rate e.g. inflation, interest rate, current account deficit, GDP growth, and foreign direct investment which we analyzed each step by step.

\section{- Inflation rate VS Exchange Rate}

In Afghanistan the inflation rate for CPI during the selected 11 years moved between $-6.81 \%$ and $26.42 \%$. For the observed period the average inflation rate was calculated to be $6.35 \%$ per year.

Figure. 1: Inflation Rate in \%

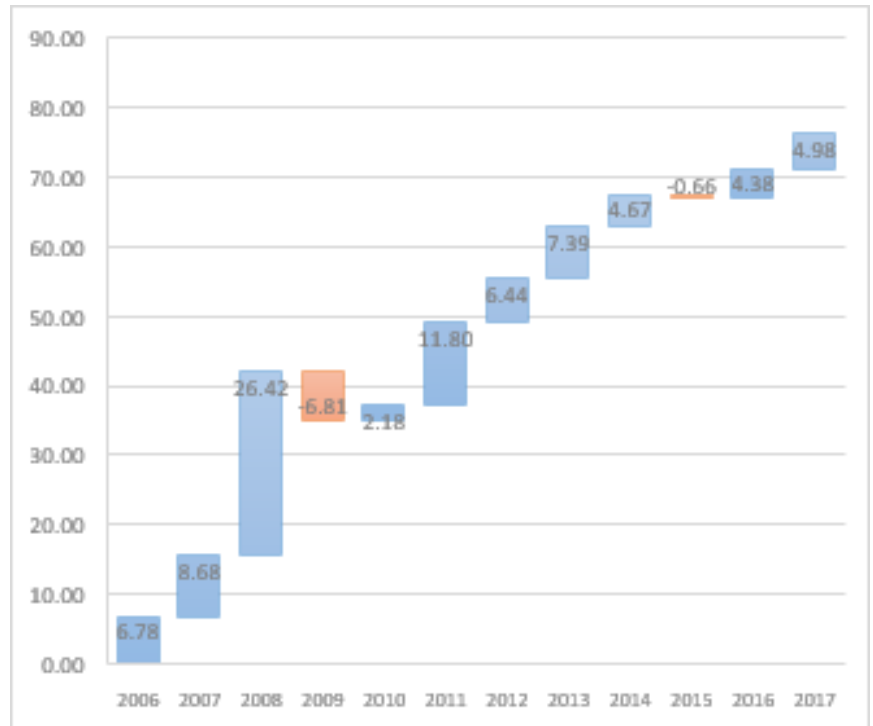

Source: World Bank, 2019
In the year 2009 and 2015 Afghanistan had negative inflation and by looking to the inflation rate of different countries, only few countries were able to achieve negative inflation which as result price level decreases and CPI got cheaper. However, as a general higher inflation rate brings depreciation in the currency of a country in relation of their trading country which at the end followed by the higher interest rate.

We looked deeper into relationship between inflation rate and exchange rate and the result shows, there is negative correlation between exchange rate and inflation by having $\mathbf{R}^{2}$ of $22.4 \%$ however, the $p$-value is not significant for $\mathbf{0 . 0 1}$ and $\mathbf{0 . 0 5}$ significance levels.

\section{- Interest Rate VS Exchange Rate}

Changes in interest rate is another economic factor which has relationship with changes in exchange rate. Theoretically, it is known that currencies which has higher interest rate attract investors who are seeking new opportunities of investment. As a result of higher interest rate, the currency will get more attractive and the demand for the money will increase, however the opposite relation is also considerable for lower interest rate.

Figure. 2: Lending Interest Rate in \%

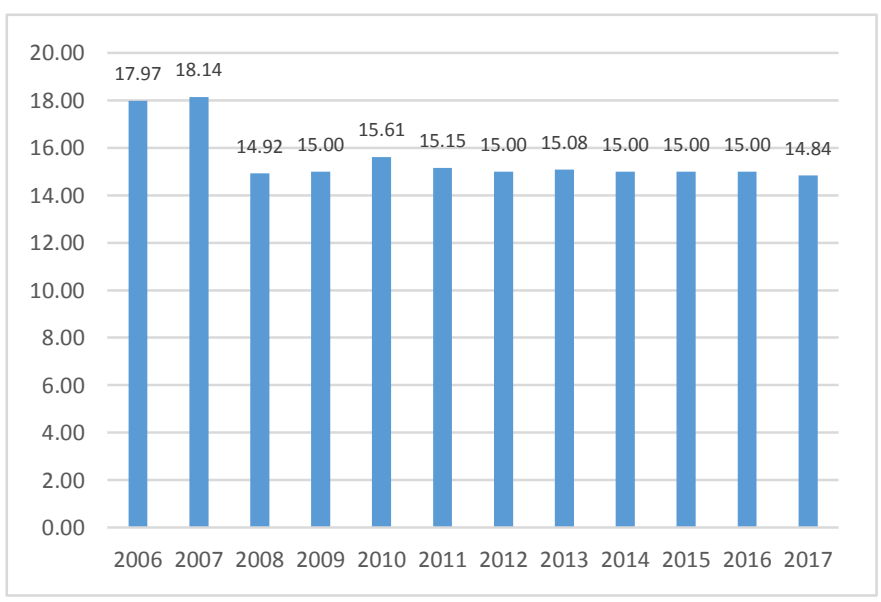

Source: World Bank, 2019

In Afghanistan the interest rate level did not change considerably and was in range of 18.14 to 14.84 percent. The average interest rate for the selected year was 15.56 percent per year.

We looked deeper into correlation between interest rate and exchange rate and the result shows, there is negative correlation between exchange rate and interest rate by having 
$\mathbf{R}^{2}$ of $\mathbf{3 6 . 4} \%$ however, the P-value is not significant for $\mathbf{0 . 0 1}$ and $\mathbf{0 . 0 5}$ significance levels.

\section{- Current Account Balance VS Exchange Rate}

The current account balance takes the record of trade between a country with the rest of the world. It shows all payment and receipts which takes place as a result of purchase or sale of goods and services or payment and receipt of dividends and interest.

When a country has deficit balance of current account, it shows that the country spends more on international trade than it earns from the international trade.

In Afghanistan, current account deficit started from 914 million USD in the year 2008 and reached to its worst deficit of 5.62 billion USD. After the year 2013 the country current account started to recover, however the deficit still exist in average value of 3.33 billion USD per year.

Figure. 3: Current Account Balance in USD

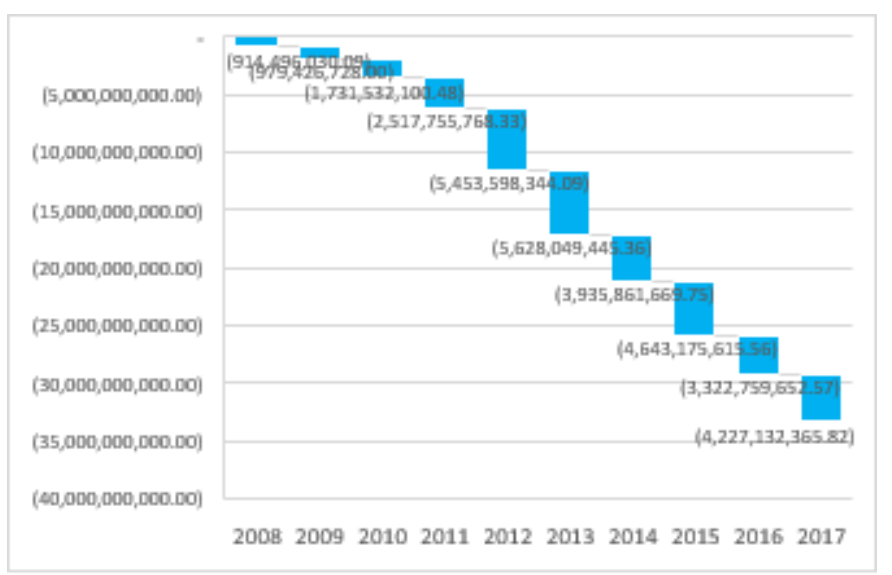

Source: World Bank, 2019

We looked deeper into correlation between current account and exchange rate. When the current account is in deficit, the value of the currency will fall as a result and opposite relationship is considerable when the current account is in surplus. The result of our analysis confirms the above explained relationship and shows, there is negative correlation between current account and exchange rate by having $\mathbf{R}^{2}$ of 44.6 \% however, the P-value is not significant at 0.01 and $\mathbf{0 . 0 5}$ levels but for $\mathbf{0 . 0 9}$ significance level.

\section{- GDP Growth VS Exchange Rate}

Afghanistan is one of the poorest countries which experienced few decades of war, but after collapse of the Taliban regime the new government received huge amount of help from its international partners and the economy started to be in steady growth. However, due to security threats and lack of infrastructure and lack of skill to manage the foreign aid, the country economic growth did not last. Countries GDP growth was 8.8 percent in 2003 which reached to its highest level of 21.3 percent in the year 2009. This GDP did not last long and turned in 2011 to its lowest level of 0.4 percent, after the country experienced political crisis and decrease in foreign aid. In the year 2018 the country had 1.03 percent GDP growth which is very low as compare to the year 2009 .

The country important sectors which plays role in GDP growth is the service sector which counts for 52 percent of GDP followed by agriculture sector with 23 percent of GDP and industry 21 percent (Trading Economics, 2019).

Figure. 4: GDP Growth (Current USD)

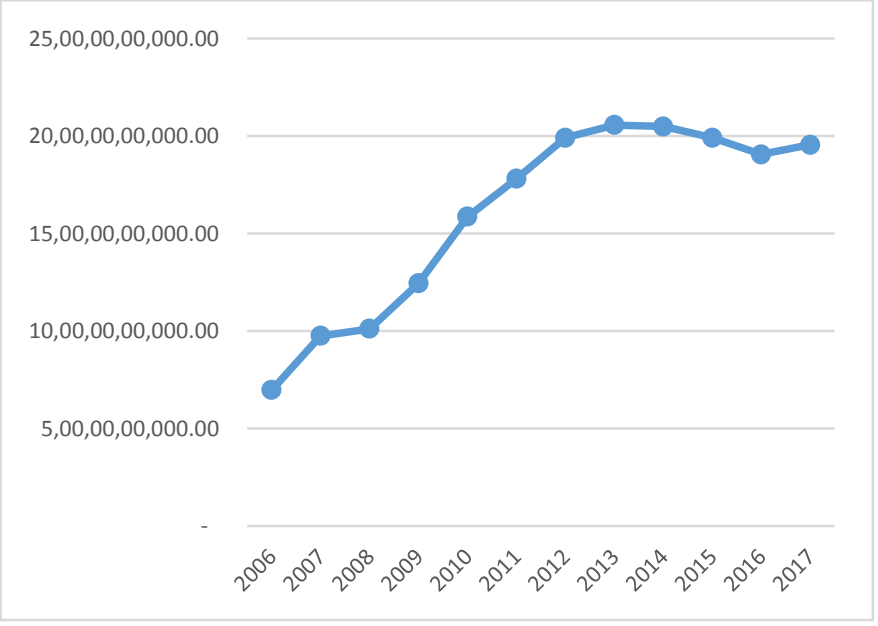

Source: World Bank, 2019

Correlation analysis between the above two variables shows that there is positive relation between GDP and exchange rate with the $\mathbf{R}^{2}$ of $\mathbf{5 2 . 4}$ percent with the significant $\mathbf{p}$-value at $\mathbf{0 . 0 5}$ level.

\section{- Foreign Direct Investment (FDI) Net Flow VS Exchange Rate}

DFI flow to Afghanistan faced with hug fluctuations during the period of 2006 to 2017. Theoretically we know, when DFI flow increases it is increasing demand for local currency which as a result the value or purchasing power of local currency increase.

During the year 2006 Afghanistan was experiencing its highest DFI which was around 250 million USD, however this 
number went down to 40.35 million in the year 2008. Most of the changes in the level of DFI was due to political crisis especially elections and security threats. In the year 2010 and 2015 the FDI flow was more than 150 million USD, however it decreased back to 53.39 million USD in the year 2017. Above data is clearly showing that FDI flow was not steady and was closely connected with political crises e.g. election of the year 2008 - 2009 and $2013-2014$.

The correlation analysis of the two variables shows the expected negative correlation in a sense, that increase in FDI reduce the value of USD and increase the value of Afghani as the data used for the analysis was the value of 1 USD versus amount of AFN in different years. The correlation of FDI flow with exchange rate is weak $\left(\mathbf{R}^{2}=\mathbf{2 5 . 7}\right)$ with insignificant $\mathrm{p}$ value at $\mathbf{0 . 0 1}$ and $\mathbf{0 . 0 5}$ levels.

Figure. 5: FDI Net Flow in USD (Million)

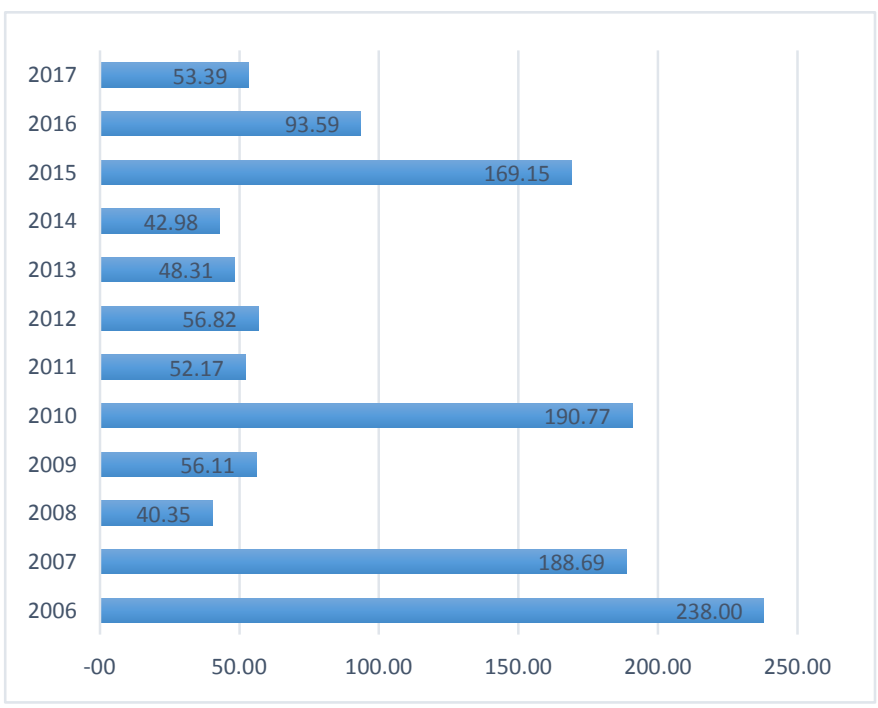

Source: World Bank, 2019

Overall, the statistical analysis of the macroeconomic indicators in respect to exchange rate rejects the null hypothesis $\left(\mathrm{H}_{0}\right)$, as it has been found that the variable exchange rate has correlation with most of the macroeconomic indicators.

\section{OLS Regression Analysis of the Models}

As is mentioned above, an OLS regression model was used to examine the relationship between the CPI, the exchange rate, and changes in the money supply. The study considered data from April 2012 to December 2018. Furthermore, to better understand the relationship between the variables, the data was sorted on a monthly basis, then used in the regression models.

\section{- Results of the First Model}

The first model considered whether the Open Market Operations (OMO) monetary policy, which is the sale of foreign currency and capital notes, influenced the exchange rate. The results were as follows.

It is important to understand how the exchange rate between the US Dollar and the Afghani was considered. In Table 1, the price of 1 US Dollar has been considered against the Afghani. The minimum exchange rate in 80 observations was 49.90 , which that means 1 US Dollar was exchanged with 49.90 Afghani. The maximum exchange rate was 75.74 . The average exchange rate over the 80 months was 1 US Dollar to 62.21 Afghani.

Table 1: Descriptive Statistics of Exchange Rate

\begin{tabular}{|c|c|c|c|c|c|}
\hline \multicolumn{6}{|c|}{ Descriptive Statistics } \\
\hline & $z$ & 官 & $\begin{array}{l}\text { z. } \\
\text { 蒿. } \\
\text { 音 }\end{array}$ & 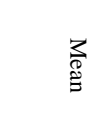 & 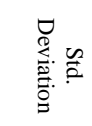 \\
\hline 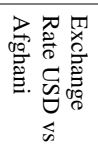 & $\stackrel{\infty}{0}$ & $\begin{array}{l}\vec{t} \\
\dot{8}\end{array}$ & $\overleftrightarrow{\breve{r}}$ & $\underset{\substack{\stackrel{N}{N}\\
}}{ }$ & 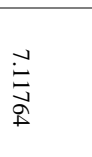 \\
\hline 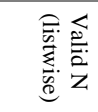 & $\stackrel{\infty}{\circ}$ & & & & \\
\hline
\end{tabular}

Table 2: List of Variables Entered/Removed

\begin{tabular}{|l|l|l|l|}
\hline Model & \multicolumn{1}{|c|}{ Variables Entered } & Variables Removed & Method \\
\hline 1 & $\begin{array}{l}\text { Capital Notes } \\
\text { Awarded in Millions } \\
\text { of USD, Foreign } \\
\text { Currency Sold in } \\
\text { Millions of USD }\end{array}$ & Enter \\
\hline a. Dependent Variable: Exchange Rate USD vs AFN & \\
\hline \multicolumn{2}{|l|}{ b. All requested variables entered } \\
\hline
\end{tabular}


Table 1 shows that in the first model, exchange rate was the dependent variable, and capital notes and foreign currency were the independent variables.

Table 3: Analysis of Variance (ANOVA)

\begin{tabular}{|l|c|c|c|c|c|}
\hline Model & $\begin{array}{c}\text { Sum of } \\
\text { Squares }\end{array}$ & df & $\begin{array}{c}\text { Mean } \\
\text { Square }\end{array}$ & F & Sig. \\
\hline Regression & $1,635.149$ & 2 & 817.575 & 26.596 & $0.000^{\mathrm{b}}$ \\
\hline Residual & $2,367.053$ & 77 & 30.741 & & \\
\hline Total & $4,002.203$ & 79 & & & \\
\hline \multicolumn{7}{|l|}{ a. Dependent Variable: Exchange Rate USD vs AFN } \\
\hline
\end{tabular}

Table 3 indicates that the regression model predicts the dependent variable (exchange rate) significantly well. A F value of 26.6 , along with a significance of $p<0.0005$, which is less than 0.05 , indicates that overall the regression model statistically significantly predicts the outcome variable and it is a good fit for the data.

Table 4: Model Summary

\begin{tabular}{|c|c|c|c|c|}
\hline Model & $\mathrm{R}$ & R Square & $\begin{array}{c}\text { Adjusted R } \\
\text { Square }\end{array}$ & $\begin{array}{c}\text { Std. Error of the } \\
\text { Estimate }\end{array}$ \\
\hline 1 & $0.639^{\mathrm{a}}$ & 0.409 & 0.393 & 5.54445 \\
\hline
\end{tabular}

Table 4 shows how much changes in the exchange rate are explained by changes in the sale of foreign currency and capital notes. The value of adjusted $\mathrm{R}^{2}$ shows that almost 39.3 percent of the variance or changes in the exchange rate are influenced by the open market operations (sale of foreign currency and capital notes). However, 60.7 percent of the changes in the exchange rate are caused by other factors not directly connected with OMO.
Table 5: Coefficients

\begin{tabular}{|c|c|c|c|c|c|c|c|c|}
\hline \multirow{2}{*}{\multicolumn{2}{|c|}{$\begin{array}{l}3 \\
0 \\
\frac{0}{0}\end{array}$}} & \multicolumn{2}{|c|}{ 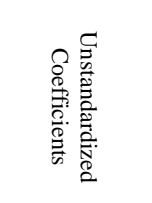 } & \multirow{2}{*}{ 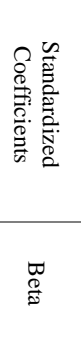 } & \multirow[t]{2}{*}{-} & \multirow[t]{2}{*}{$\frac{y^{2}}{9}$} & \multicolumn{2}{|c|}{ 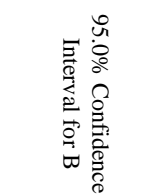 } \\
\hline & & $\varpi$ & 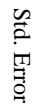 & & & & 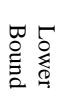 & 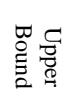 \\
\hline \multirow[t]{3}{*}{-} & 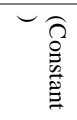 & : & $\underline{ \pm}$ & & $\begin{array}{l}\underset{w}{w} \\
\infty \\
\infty \\
+\infty\end{array}$ & $\dot{8}$ & 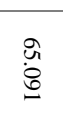 & 岕 \\
\hline & 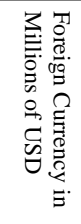 & 定 & $\begin{array}{l}\dot{0} \\
\dot{\infty}\end{array}$ & $\begin{array}{l}\dot{1} \\
\text { tे }\end{array}$ & $\begin{array}{l}\dot{u} \\
\ddot{\omega} \\
\dot{\omega}\end{array}$ & $\dot{8}$ & 总 & 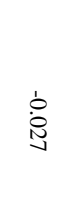 \\
\hline & 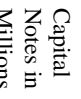 & $\stackrel{\ominus}{\varrho}$ & 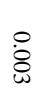 & 岕 & $\begin{array}{l}w \\
\stackrel{b}{0} \\
\sigma\end{array}$ & $\dot{8}$ & 客 & $\stackrel{\circ}{\circ}$ \\
\hline
\end{tabular}

Table 5 provides the information required to predict changes in the exchange rate resulting from the sale of foreign currency and capital notes by DAB. By looking at the coefficient of foreign currency $(-0.042)$, we can conclude that by selling one million USD, DAB can reduce the price of US dollars by 0.042 Afghani. As expected from the theory of money supply, the coefficient has a negative value, which means that selling USD reduces their value compared to the Afghani. Furthermore, the sale of capital notes has a positive impact on the exchange rate, which means that $\mathrm{DAB}$ cannot increase the demand for Afghani by injecting more capital notes into the market. The value of capital notes used for this analysis is measured in USD. However, DAB issues the notes in Afghani in order to create demand for Afghani. Theoretically, when the demand for Afghani rises, the value of the US Dollar against the Afghani should reduce. However, the results of this study show the opposite effect for capital notes. By looking at the absolute values of the t- (5.53 and 3.97) and p-values ( $<0.0001)$, it is clear that the coefficients are significant at the one percent level.

\section{- Results of the Second Model}

The second model in the study examined the impact of changes in the amounts of narrow and broad money in 
circulation on the CPI. The basic idea behind this analysis is to examine the impact of money supplied to the market on price stability. The model uses the CPI as a proxy for the price of goods. After running the regression, we have the following results.

Table 6: List of Variables Entered/Removed

\begin{tabular}{|c|c|c|c|}
\hline \multirow{3}{*}{ Model } & Variables Entered & $\begin{array}{l}\text { Variables } \\
\text { Removed }\end{array}$ & Method \\
\hline 1 & $\begin{array}{l}\text { Broad Money M2 in } \\
\text { Millions of Afghani, } \\
\text { Narrow Money M1 in } \\
\text { Millions of Afghani }\end{array}$ & Enter \\
\hline & \multicolumn{2}{|c|}{ a. Dependent Variable: CPI } & \\
\hline \multicolumn{2}{|c|}{ b. All requested variables entered } \\
\hline
\end{tabular}

In the regression model, the dependent variable is the CPI and the independent variables are M1 and M2.

Table 7: Model Summary

\begin{tabular}{|l|c|c|c|c|}
\hline Model & $\mathrm{R}$ & R Square & $\begin{array}{c}\text { Adjusted R } \\
\text { Square }\end{array}$ & $\begin{array}{c}\text { Std. Error of } \\
\text { the Estimate }\end{array}$ \\
\hline 1 & $0.686^{\mathrm{a}}$ & 0.471 & 0.457 & 4.70173 \\
\hline
\end{tabular}

In Table 7, the value of $\mathrm{R}(0.686)$ shows a strong correlation between the observed and predicted values of the dependent variable. Furthermore, the values of $\mathrm{R}^{2}(0.471)$ and adjusted $\mathrm{R}^{2}(0.457)$ show that almost 45 percent of the variance in the price of goods (CPI) is explained by the variables M1 and M2. The remaining 55 percent of the variance in prices is caused by other factors. These other factors could be related to fiscal policy or other small measures of monetary policy which are not discussed in this study.

Table 8: Analysis of Variance (ANOVA) ${ }^{\mathrm{a}}$

\begin{tabular}{|c|c|c|c|c|c|c|}
\hline \multicolumn{2}{|c|}{ Model } & \multirow{2}{*}{$\begin{array}{c}\begin{array}{r}\text { Sum of } \\
\text { Squares }\end{array} \\
\end{array}$} & \multirow{2}{*}{$\begin{array}{l}\text { df } \\
\text { N }\end{array}$} & \multirow{2}{*}{ 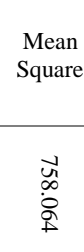 } & \multirow{2}{*}{ 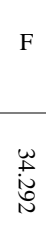 } & \multirow{2}{*}{$\begin{array}{r}\text { Sig } \\
\\
\\
\stackrel{8}{8}\end{array}$} \\
\hline 1 & 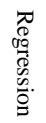 & & & & & \\
\hline & 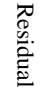 & $\begin{array}{l}\stackrel{-}{\circ} \\
\stackrel{\sim}{\circ} \\
\stackrel{\infty}{\infty}\end{array}$ & $y$ & $\stackrel{N}{\stackrel{N}{\circ}}$ & & \\
\hline & $\stackrel{-1}{\stackrel{0}{ٍ}}$ & $\begin{array}{l}\underset{\sim}{N} \\
\stackrel{\infty}{\infty} \\
\stackrel{\infty}{\omega}\end{array}$ & రి & & & \\
\hline \multicolumn{7}{|c|}{ a. Dependent Variable: CPI } \\
\hline \multicolumn{7}{|c|}{$\begin{array}{l}\text { b. Predictors: (Constant), Broad Money M2 in Millions of Afghani, Narrow Money } \\
\text { M1 in Millions of Afghani }\end{array}$} \\
\hline
\end{tabular}

Table 8 tests whether the $\mathrm{R}^{2}$ value is significantly greater than zero or not. By looking at the p-value, which is less than 0.05 ( $p<0.0001$ ), we can see that $\mathrm{R}^{2}$ is significantly greater than zero, and our predictors are able to account for a significant amount of the variance in the price of goods. In other words, the ANOVA table shows that the overall regression model is significant, with $\mathrm{F}(2,77)=34.292, \mathrm{p}<0.001$ and $\mathrm{R}^{2}=0.471$. Table 9: Coefficients ${ }^{\mathrm{a}}$

\begin{tabular}{|c|c|c|c|c|c|}
\hline \multirow[t]{2}{*}{ Model } & \multicolumn{2}{|c|}{$\begin{array}{l}\text { Unstandardized } \\
\text { Coefficients }\end{array}$} & \multirow{2}{*}{$\begin{array}{c}\begin{array}{c}\text { Standardized } \\
\text { Coefficients }\end{array} \\
\text { Beta }\end{array}$} & \multirow{2}{*}{$\mathrm{t}$} & \multirow{2}{*}{ Sig. } \\
\hline & B & $\begin{array}{l}\text { Std. } \\
\text { Error }\end{array}$ & & & \\
\hline 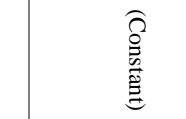 & $\begin{array}{l}\stackrel{\circ}{\ddagger} \\
\stackrel{0}{\circ}\end{array}$ & $\stackrel{\text { à }}{ }$ & & $\begin{array}{l}\not{f} \\
\dot{8} \\
+\end{array}$ & $\begin{array}{l}\circ \\
\dot{8}\end{array}$ \\
\hline 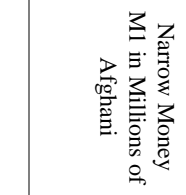 & $\stackrel{\circ}{\stackrel{8}{0}}$ & ᄋ & $\begin{array}{l}v \\
\stackrel{u}{u}\end{array}$ & $\begin{array}{l}v \\
\text { in } \\
\infty\end{array}$ & $\begin{array}{l}\circ \\
\dot{8}\end{array}$ \\
\hline 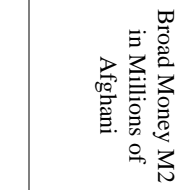 & $\begin{array}{l}\dot{0} \\
8 \\
8\end{array}$ & $\stackrel{\circ}{8}$ & 立 & $\begin{array}{l}\dot{1} \\
\dot{\infty} \\
\stackrel{+}{N}\end{array}$ & 용 \\
\hline $\begin{array}{l}\text { a. Dependent } \\
\text { Variable: CPI }\end{array}$ & & & & & \\
\hline
\end{tabular}


Table 9 provides the information required to predict changes in the CPI resulting from changes in M1 and M2. By looking at the coefficient of M1 (0.001), we can conclude that increasing the amount of narrow money in the market by one million Afghani would increase the CPI by 0.001 Afghani, which makes sense theoretically. However, the impact is not very strong. Furthermore, the coefficient of M2 shows that it has a negative impact on prices, which means that when the amount of convertible assets in the market increases, prices will decrease. This goes against the theory, as M2 is also considered money in circulation. However, the changes in the CPI due to changes in M2 are also not very strong. The pvalues of the coefficients shows that the coefficients are significant at the one percent level.

The values of the coefficients show that M1 and M2 do not strongly influence the price of goods. The main arguments made in the context of Afghanistan are that changes in the CPI are more connected with seasonal factors, political stability, and the relationships with neighboring countries.

\section{- Unit Root Test}

We performed a unit root test to check whether the data related to the CPI and the exchange rate were stationary. The results of the unit root test for the CPI are shown in Appendix 1. They show that both the intercept and the trend at the first level have a unit root. However, after removing out the first difference, the null hypothesis (that the CPI has a unit root) was rejected, and the data was shown to be stationary. By looking at the overall trend in the CPI in Appendix 2, it can be seen that it was important to perform a unit root test.

Similarly, as is noticeable from the graph of exchange rate in Appendix 4, the exchange rate between the US Dollar and the Afghani has an upward trend, which makes it necessary to do a unit root test. The results of the test are given in Appendix 3. They show that when the test was done on the original data, the exchange rate data had a unit root, but after removing out the first difference, the exchange rate was shown to be stationary. Therefore, there was no need to do a co-integration test to look for long-term relationships between the variables.

\section{DISCUSSION AND CONCLUSION}

The empirical analysis of this study has revealed that DAB's monetary policy can control the exchange rate. One of the monetary policy tools which DAB uses is selling foreign currency to control the exchange rate and the Afghani's purchasing power. The results of the study show that selling foreign currency (USD) has a negative impact on the exchange rate, so that one USD is worth less Afghani. The $\mathbf{R}^{2}$ value of the data suggests that DAB's policies only influence 40 percent of the changes in the exchange rate. The other 60 percent of changes are caused by other factors, which the government should consider.

The relationship between the CPI, which is the prices of goods, and the amount of money in circulation was analyzed in in the second model and found to be weak. However, when the amount of cash in circulation increases, prices will also increase, but this increase in prices is not huge. Furthermore, the results showed that $\mathrm{DAB}$ could control prices, but only with very large amounts of money, as there are other factors which cause changes in the CPI. By looking closer at the list of goods considered by the CPI, it can be seen that those goods which are produced in Afghanistan have seasonal fluctuations. This means that the prices of goods which are produced or grow by farmers in Afghanistan are reduced when they are in season and increase when the production/growing season is over. Furthermore, political instability and relationships with neighboring countries from which we import some necessary goods also cause changes in the CPI.

\section{REFERENCES}

1. Akinbobola, T. O. (2012). The Dynamics of Money Supply, Exchange Rate \& Inflation in Nigeria. Journal of Applied Finance \& Banking, 2 (4), 117141.

2. Amarasekara, C. (2007). The Impact of Monetary Policy on Economic Growth and Inflation in Sri Lanka. Staff Studies 38 (1\&2), 110.

3. Babatunde and Kehinde (2016). The impact of monetary policy on price stability in Nigeria. Global Journal of Economics and Business Administration (GJEBA),1(1): 0001-0026.

4. Chuku, C. A. (2009). Measuring the effects of Monetary Policy Innovations in Nigeria. African Journal of Accounting, Economics, Finance \& Banking Research, 5 (5), 141-153.

5. Da Afghanistan Bank. (2003). Da Afghanistan Bank Law. Published in Afghanistan Official Gazette.

6. Da Afghanistan Bank. (2018). Da Afghanistan Bank Report. Published by DAB.

7. Folawewo, A. O. \& Osinubi, T. S. (2008). Monetary Policy \& Macroeconomic Instability in Nigeria: A Rational Expectation Approach. Published by Journal of Economics.

8. Index Mundi online portal. (2019). https://www.indexmundi.com/g/g.aspx?c=af\&v=71 (Retrieved date: 22/05/2019). 


\section{International Journal of Engineering Applied Sciences and Technology, 2019 \\ Vol. 4, Issue 4, ISSN No. 2455-2143, Pages 19-28 \\ Published Online August 2019 in IJEAST (http://www.ijeast.com)}

9. Manohar Rao. (2003). Science of Monetary Policy: Some perspectives on the Indian economy. Economic and Political Weekly, 38 (8), 809-820.

10. Nenbee, S. G. \& Madume, J. (2011). The Impact of Monetary Policy on Nigeria's Macroeconomic Stability. International Journal of Economic Development Research \& Investment, 2 (2), 174-183.

11. Svensson, L. E. (1999). Inflation targeting as a monetary policy rule. Journal of Monetary Economics, 43 (3), 607-654.

12. Trading Economics online portal. (2019). https://tradingeconomics.com/afghanistan/gdpgrowth-annual (Retrieved date: 25/05/2019).

13. World Bank Data Portal. (2019). https://data.worldbank.org/country/afghanistan (Retrieved date: 21/04/2019)

\section{APPENDICES}

Appendix 1: Unit Root Test of the CPI

Null Hypothesis: D(CPI_OVERALL_IN_AFN) has a unit root
Exogenous: Constant, Linear Trend
\begin{tabular}{lccc} 
& & \\
Lag Length: 0 (Automatic - based on SIC, maxlag=11) & & \\
\hline \hline & t-Statistic & Prob. $^{*}$ \\
\hline \hline Augmented Dickey-Fuller test statistic & -8.777284 & 0.0000 \\
\hline Test critical values: & $1 \%$ level & -4.080021 & \\
& $5 \%$ level & -3.468459 & \\
& $10 \%$ level & -3.161067 & \\
\hline
\end{tabular}

*MacKinnon (1996) one-sided p-values

Augmented Dickey-Fuller Test Equation Dependent Variable: D(CPI_OVERALL_IN_AFN,2)

Method: Least Squares

Date: 01/27/19 Time: 15:17

Sample (adjusted): 2012M06 2018M11

Included observations: 78 after adjustments

\begin{tabular}{lrlll}
\hline \hline \multicolumn{1}{c}{ Variable } & Coefficient & Std. Error & t-Statistic & Prob. \\
\hline \hline D(CPI_OVERALL_IN_AFN(-1)) & -1.014399 & 0.115571 & -8.777284 & 0.0000 \\
C & 0.340518 & 0.602751 & 0.564941 & 0.5738 \\
\multicolumn{1}{c}{ @TREND("2012M04") } & -0.007252 & 0.013009 & -0.557479 & 0.5789 \\
\hline \hline R-squared & 0.506729 & Mean dependent var & 0.005017 \\
Adjusted R-squared & 0.493576 & S.D. dependent var & 3.625511 \\
S.E. of regression & 2.580041 & Akaike info criterion & 4.771190 \\
Sum squared resid & 499.2459 & Schwarz criterion & 4.861833 \\
Log likelihood & -183.0764 & Hannan-Quinn criter. & 4.807476 \\
F-statistic & 38.52318 & Durbin-Watson stat & 1.996711 \\
Prob(F-statistic) & 0.000000 & & & \\
\hline \hline
\end{tabular}

Appendix 2: Overall Trend in CPI

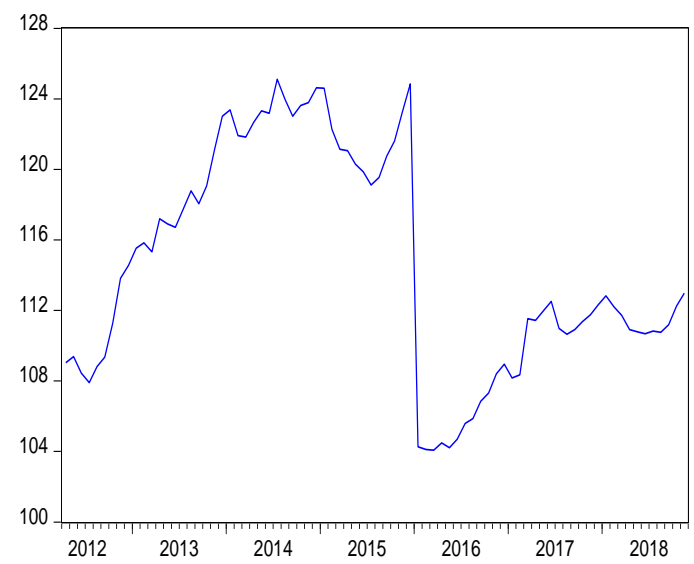

Appendix 3: Unit Root Test of the Exchange Rate

Null Hypothesis: D(EXCHANGE_RATE_USD) has a unit root Exogenous: Constant, Linear Trend

Lag Length: 0 (Automatic - based on SIC, maxlag=11)

\begin{tabular}{lccc}
\hline \hline & t-Statistic & Prob.* $^{*}$ \\
\hline \hline Augmented Dickey-Fuller test statistic & -7.441031 & 0.0000 \\
\hline Test critical values: & $1 \%$ level & -4.080021 & \\
& $5 \%$ level & -3.468459 & \\
& $10 \%$ level & -3.161067 & \\
\hline \hline
\end{tabular}

*MacKinnon (1996) one-sided p-values.

Augmented Dickey-Fuller Test Equation

Dependent Variable: D(EXCHANGE_RATE_USD,2)

Method: Least Squares

Date: 01/27/19 Time: 15:19

Sample (adjusted): 2012M06 2018M11

Included observations: 78 after adjustments

\begin{tabular}{lrllr}
\hline \multicolumn{1}{c}{ Variable } & Coefficient & \multicolumn{1}{c}{ Std. Error } & t-Statistic & Prob. \\
\hline \hline D(EXCHANGE_RATE_USD(-1)) & -0.850347 & 0.114278 & -7.441031 & 0.0000 \\
C & 0.244859 & 0.174982 & 1.399338 & 0.1658 \\
\multicolumn{1}{c}{ @TREND("2012M04") } & 0.000858 & 0.003721 & 0.230614 & 0.8182 \\
\hline \hline R-squared & 0.424759 & Mean dependent var & -0.001228 \\
Adjusted R-squared & 0.409419 & S.D. dependent var & 0.961705 \\
S.E. of regression & 0.739064 & Akaike info criterion & 2.270837 \\
Sum squared resid & 40.96612 & Schwarz criterion & 2.361479 \\
Log likelihood & -85.56263 & Hannan-Quinn criter. & 2.307123 \\
F-statistic & 27.69005 & Durbin-Watson stat & 2.019005 \\
Prob(F-statistic) & 0.000000 & & & \\
\hline \hline
\end{tabular}

Appendix 4: Overall Trend in Exchange Rate

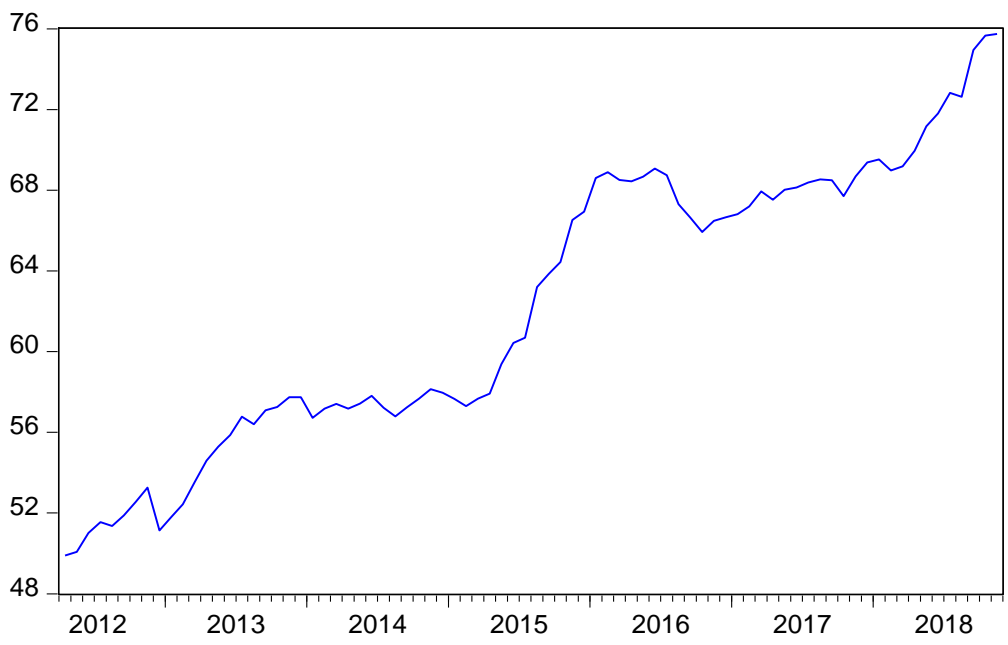

